\title{
Qualimetric Approach to Assessment Educational Achievements of Graduates
}

\author{
Belevitin V.A. ${ }^{1,}$ Salamatov A.A. ${ }^{2,}$ Gafarova E.A. ${ }^{1,}$ Gordeeva D.S. ${ }^{1}$ \\ ${ }^{I}$ South Ural State Humanitarian and Pedagogical University \\ ${ }^{2}$ Chelyabinsk State University \\ ${ }^{*}$ Corresponding author. Email: gafarovaea@cspu.ru
}

\begin{abstract}
Introduction. Socio-economic transformations in Russia and the urgent need to meet the inevitable new demands of society and employers in ensuring technological safety associated with human factors have given priority to the problem of increasing the degree of formation of professional competencies of university graduates. The personal professional level of university graduates is objectively a socially significant quality of its readiness for effective and flexible work in the conditions of technical, technological, environmental, economic, managerial and educational changes to ensure the achievement of the main goals of safe and sustainable development of society. There is an obvious need for the definition and justification of scientifically based organizational and pedagogical conditions for the qualimetric assessment of control and measuring materials for educational achievements of university graduates.

The goal is to present the results of a study of organizational and pedagogical conditions that contribute to increasing the reliability of the obtained results of test diagnostics of knowledge, skills and the degree of formation of professional competencies of university graduates.

Methodology and research methods. The work was carried out based on the provisions of modern approaches and models of qualimetric monitoring (V.G. Gorb, L.N. Davydova, N.F. Efremova, N.A. Kulemin, A.N. Mayorov, D.Sh. Matros, M.M. Potashnik, A.I. Pulbere, E.I. Sakharchuk, etc.) educational achievements of students of educational organizations. The main research methods were a theoretical analysis of materials published in the scientific literature on the problem of assessing the degree of formation among students, primarily practice-oriented professional competencies, their level structuring, as well as a generalization of the monitoring features of practice-oriented professional competencies of university graduates. The main sources of development of pedagogical tools for assessing the degree of formation of professional competencies of university graduates were the domestic experience of professional training of masters in the areas of training "Management (human capital management)" and "Professional training (by industry)."

Results. The conditions for conducting an expert assessment and modeling the degree of influence of such factors of pedagogical tests as their content $S$, representativeness of the structure $\mathrm{R}$ and latency $\mathrm{L}$ on the value of the "objectivity" of pedagogical tests are described.

Scientific novelty consists in a qualimetric assessment of the degree of influence of the factors of pedagogical tests S, R and L on the value of the "objectivity" of pedagogical tests using mathematical modeling by scientifically based application of objective statistical methods.

The practical significance lies in the fact that the need for a qualimetric approach is justified in providing a more accurate and adequate assessment of the professional training of university graduates in the face of overcoming the objective difficulties of continuous and rapidly occurring changes in all areas of society.

Keywords: qualimetric approach, pedagogical testing, educational achievements, expert assessment,
\end{abstract}

mathematical modeling

\section{INTRODUCTION}

The socio-economic transformations taking place in Russia today, as a result of the transition to market relations, and the urgent need to satisfy the inevitably new demands of society, employers and university graduates themselves objectively put forward the number of priority issues in improving the quality of training for professional cadres with a higher degree of professional competencies in the field of safe and sustainable development [1-5]. An analysis of the conformity of the vocational training of graduates convincingly indicates not so much about the 
insufficient, fragmented coverage of the subject area of the needs of the modern post-information society, but about the "chronic" lag behind its urgently needed needs [6-8], the requirements of professional standards in terms of degree of compliance professional competencies, the sixth level of the National Qualifications Framework of the Russian Federation [9-11]. The aforementioned is confirmed by the fact that the problem of ensuring safe and sustainable development by $70 \%$ is associated with the human factor [12] and unsatisfactory training of personnel for effective and flexible work under the conditions of technical, technological, environmental, economic, managerial and educational changes [13-16].

\section{PROBLEM STATEMENT}

The current situation of total digitalization of public processes actualizes the problem of developing innovative principles for the professional training of specialists. A methodically competent assessment of the degree of conformity of professional competencies is the key to an effective response to the requests of the public, employers and students themselves, for whom it is also important to know the criteria by which they will be evaluated their readiness for the profession as a whole, and for the qualitatively efficient performance of their work in a particular workplace, the ability to quickly respond to changes in different areas of public life. The problem is largely due to the objective need to develop innovative pedagogical tools for an objective quantitative assessment of the degree of conformity of the professional competencies of university graduates as a set of interconnected tools (methods, techniques, techniques and tools) of the pedagogical interaction of subjects and objects of the educational process [19-20]. Training based on the conceptual principles and methods of pedagogy, measurements, mathematical modeling and mathematical statistics of the qualimetric approach with widespread use of ICT allows you to study and analyze the influence of various factors on the learning process, choose the optimal strategies, teaching methods and methods of generating educational trajectories $[1 ; 21-23]$. In the light of this approach, the special importance of the qualimetric approach to assessing students 'educational achievements is updated by conceptual studies within the framework of the "Program for International Student Assessment (PISA)" [8] and the development of innovative methods of pedagogical control of the degree of compliance of graduates' professional competencies universities proposed by I.D. Stolbovoy and A.N. Danilov, D.G. Miroshin [2426], O.F. Shikhova and Yu.A. Shikhov [27], M.V. Potapova [19].

\section{MATERIALS AND METHODS}

The research materials were modern approaches, algorithms and models of qualimetric monitoring (V.G.
Gorb, L.N. Davydova, N.F. Efremova, N.A. Kulemin, A.N. Mayorov, D.Sh. Matros, M .M. Potashnik, A.I. Pulbere, E.I. Sakharchuk, etc.) educational achievements of students of educational organizations. The main research methods were the theoretical analysis of materials published in the scientific literature on the problem of assessing the degree of formation among students, first of all, practice-oriented professional competencies, their level structuring, as well as a generalization of the monitoring features of practice-oriented professional competencies of university graduates, since at present the first plan for employers is the ability to freely own potential candidates with different behaviors Skim the skills to successfully interact with others, including the ability to work in a virtual team, timely information processing and flexible response to changes in the environment, as well as those of their quality as a cross-cultural, transdisciplinary, and adaptive thinking [27-28].

The main sources of development of pedagogical tools for assessing the degree of formation of professional competencies of university graduates were the domestic experience of professional training of masters in the areas of training "Management (human capital management)" and "Professional training (by industry)"; theoretical concepts reflecting the current level of development of professional teacher education; practical experience in the formation of practice-oriented professional competencies of university graduates.

To achieve an objective assessment of the real preparedness of university graduates to the modern demands of society, employers and students themselves, it is not enough fragmentary and unsystematic monitoring of students' academic achievements, which prevents the activation of the most important educational sources for mastering professionalism and improving their subjective properties that are professionally significant. Obtaining complete and objective information for taking reasonable measures to improve the quality of education, aligning the level of professional education and the needs of the modern labor market largely depends on the correctness of expert estimates of the difficulty level of test tasks, their objectivity due to the use of weighting factors for each of the evaluated factors when using the method of prioritization in accordance with the necessary requirements for the content of tests for their high scientific validity and representativeness, first of all [29], as well as validity, latency, cognitiveness, discriminativity and, in general, reliability (determining the reproducibility of test results, their accuracy), the answers to which, in many cases, still abound with significant difficulties [3031]. The main goal of the pedagogical measurement as an applied theory of scientific pedagogy [32] is to develop tests of objective control of the preparedness of students. According to the results of the study [33-35], qualitatively made, qualimetrically verified tests with pre-designed technologies of standardized procedures for conducting, processing and analyzing the results [36], unlike a set of control tasks, allow solving the problem of objectification of pedagogical measurements and, on this basis, improving modern education through the direct connection of 
objectivity of the pedagogical tests [37-39], namely, such factors of pedagogical tests as their content $\mathrm{S}$, representativeness of the structure $\mathrm{R}$, and latency $\mathrm{L}$ [39]. As a result of applying the method of group expert assessment, which makes it possible to increase the level of objectivity of estimates and judgments of a certain number of expert experts (more than two) using the procedures of bringing individual opinions to a single, group, taking into account differences in the knowledge, competence and objectivity of experts with real leveling their "inequality" and statistical processing of the results of surveys of independent experts at extreme values of the "importance" coefficients ci, $\mathrm{i}=1,2,3$ factors $\mathrm{S}, \mathrm{R}$ and $\mathrm{L}$ pedagogical tests, the values of the degree of their influence on the value of PT are obtained: $0,67 \leq \mathrm{S} \leq 0,85$; $0,73 \leq \mathrm{R} \leq 0,87 ; 0,60 \leq \mathrm{L} \leq 0,70$. At the same time, the final (group, collective) assessment was defined as the weighted average competence of expert preparedness:

$\mathrm{X} i=q j \mathrm{X} 11+q j \mathrm{X} 12+q j \mathrm{X} 13+\cdots .+q j \mathrm{X} i j(1)$ where: $\mathrm{Xi}$ - the final group assessment of the ranking of the i-th factor of pedagogical tests;

$\mathrm{Xij}$ - an individual ranking ranking of the $\mathrm{i}$-th factor of pedagogical tests by the $\mathrm{j}$-th expert;

qj - competence, preparedness of the $j$-th expert.

It is convenient to write down the conditions of the planned experiment to identify the degree of influence of the $\mathrm{S}, \mathrm{R}$, and $\mathrm{L}$ factors on the indicator ò in the form of a fractional matrix 23-1 (Table 1), where the rows correspond to different experiments, and the columns correspond to the values of the statistical processing of the results of surveys of independent experts of three variable factors. ), were asked to rank the factors selected from literature based on the analysis of the opinions of researchers according to the degree of their influence on the value of

Table 1 Plan for fractional factorial experiment $2^{3-1}$ and the results of the study of the value of the indicator ò

\begin{tabular}{|c|c|c|c|c|c|c|c|c|c|}
\hline \multirow[t]{2}{*}{$\begin{array}{c}\text { Experience } \\
\text { number }\end{array}$} & \multicolumn{2}{|c|}{ Content $S$} & \multicolumn{2}{|c|}{$\begin{array}{c}\text { Representativeness } \\
\text { of the structure } R\end{array}$} & \multicolumn{2}{|c|}{$\begin{array}{c}\text { Latency } \\
\quad L\end{array}$} & \multicolumn{3}{|c|}{$\begin{array}{c}\text { Values (õi), } i=1,2,3,4 \text { for } \\
\text { importance coefficient levels: }\end{array}$} \\
\hline & $\begin{array}{c}\text { Coded } \\
\text { value }\end{array}$ & $\begin{array}{c}\text { Natur } \\
\text { al } \\
\text { value }\end{array}$ & $\begin{array}{c}\text { Coded } \\
\text { value }\end{array}$ & $\begin{array}{c}\text { Natural } \\
\text { value }\end{array}$ & $\begin{array}{c}\text { Cod } \\
\text { ed } \\
\text { valu } \\
\text { e }\end{array}$ & $\begin{array}{c}\text { Natural } \\
\text { value }\end{array}$ & $\begin{array}{c}\text { Lower } \\
(-1)\end{array}$ & $\begin{array}{c}\text { Middle } \\
\text { (0) }\end{array}$ & $\begin{array}{l}\text { Top } \\
(+1)\end{array}$ \\
\hline 1 & +1 & 0,85 & +1 & 0,87 & +1 & 0,70 & 0,900 & 0,876 & 0,852 \\
\hline 2 & +1 & 0,85 & -1 & 0,73 & -1 & 0,60 & 0,857 & 0,833 & 0,809 \\
\hline 3 & -1 & 0,67 & -1 & 0,73 & +1 & 0,70 & 0,783 & 0,744 & 0,706 \\
\hline 4 & -1 & 0,67 & +1 & 0,87 & -1 & 0,60 & 0,805 & 0,767 & 0,728 \\
\hline
\end{tabular}

The coefficients of the mathematical model in the form of a linear equation for the regression of the exponent ò for various intervals of variation of the coefficients of "importance" of factors S, R and L (table 2) were statistically verified by the values of asymmetry (A), Wilcoxon and Cochren criteria with the calculation of confidence intervals. As a result, their adequacy and ability to use in the development, as well as testing, certification and implementation of pedagogical tests, are shown. The developed mathematical models based on clear formalized rules allow you to: a) minimize the error of the experiment by selecting and applying objective plans for the implementation of experiments; b) evaluate the influence of control factors. 
To study the degree of influence of the factors of pedagogical tests $\mathrm{S}, \mathrm{R}$ and $\mathrm{L}$ depending ò $=\mathrm{o}(\mathrm{S}, \mathrm{R}, \mathrm{L})$, we used mathematical design of the experiment according to the type of Latin $4 \times 4$ square (table 3 ). Each of the three factors $\mathrm{S}, \mathrm{R}$ and $\mathrm{L}$ was assigned at four (and not two, as before) levels, which is why planning is called by the type of Latin $4 \times 4$ square. The levels of variation of the $S$-factor of pedagogical tests $(\mathrm{bi}=0.67 ; \ldots, 0.85)$ correspond to the rows of table 3 , the columns correspond to the levels of the R-factor of the structure of the PT (ai $=0.73 ; \ldots ; 0.88)$; The L-factor of pedagogical tests varied from $\mathrm{ci}=0.59$ to $\mathrm{ci}=$ 0.71 (in the cells of table 3 ). The final values ò of pedagogical tests are also presented in the cells of table 3: $\begin{array}{llll}\text { ò } & = & 0.721 ; & \ldots\end{array}$

Table 2 Coefficients of the linear equation of regression of the exponent ò

\begin{tabular}{|c|c|c|c|c|c|}
\hline \multirow{2}{*}{$\begin{array}{c}\text { Interval } \\
\text { changes } \boldsymbol{c}_{\boldsymbol{s}}\end{array}$} & \multicolumn{4}{|c|}{ The coefficients of the equation } & \multirow{2}{*}{$\begin{array}{c}\text { Confidence interval } \\
\mathbf{n} \boldsymbol{\Delta} \boldsymbol{d}_{\boldsymbol{i}}, \boldsymbol{i}=\mathbf{1 , 2 , 3}\end{array}$} \\
\cline { 2 - 5 } & $\boldsymbol{d}_{\mathbf{0}}$ & $\boldsymbol{d}_{\mathbf{1}}$ & $\boldsymbol{d}_{\mathbf{2}}$ & $\boldsymbol{d}_{\mathbf{3}}$ & 0,0018 \\
\hline $0,43-0,51$ & 0,836 & 0,042 & 0,016 & 0,005 & 0,0013 \\
\hline $0,51-0,59$ & 0,805 & 0,005 & 0,016 & 0,005 & 0,0015 \\
\hline $0,59-0,67$ & 0,774 & 0,057 & 0,016 & 0,005 & \\
\hline
\end{tabular}

Table 3 The plan and results of the study ò the type of Latin square $4 \times 4$

\begin{tabular}{|c|c|c|c|c|c|c|}
\hline \multirow{2}{*}{$\mathbf{S}\left(\mathbf{b}_{\mathbf{i}}\right)$} & \multicolumn{4}{|c|}{$\mathbf{R}\left(a_{i}\right)$} & \multirow{2}{*}{$\tilde{\mathbf{o}}_{j}$} & \multirow{2}{*}{$\tilde{\mathbf{o}}_{k}$ at $c_{i}$} \\
\hline & $a_{1}=0,73$ & $a_{2}=0,78$ & $a_{3}=0,83$ & $a_{4}=0,88$ & & \\
\hline \multirow[b]{2}{*}{$b_{1}=0,67$} & $c_{1}=0,59$ & $c_{2}=0,63$ & $c_{3}=0,67$ & $c_{4}=0,71$ & \multirow[t]{2}{*}{0,745} & \multirow{2}{*}{$\begin{array}{c}c_{1}=0,59 \\
\tilde{\mathrm{o}}=0,788\end{array}$} \\
\hline & $\grave{\mathrm{o}}=0,721$ & $\grave{\mathrm{o}}=0,737$ & $\grave{\mathrm{o}}=0,752$ & $\grave{\mathrm{o}}=0,768$ & & \\
\hline \multirow[b]{2}{*}{$b_{2}=0,73$} & $c_{2}=0,63$ & $c_{1}=0,59$ & $c_{4}=0,71$ & $c_{3}=0,67$ & \multirow[t]{2}{*}{0,779} & \multirow{2}{*}{$\begin{array}{l}c_{2}=0,63 \\
\tilde{\hat{o}}=0,792\end{array}$} \\
\hline & $\grave{\mathrm{o}}=0,758$ & $\grave{\mathrm{o}}=0,766$ & $\grave{\mathrm{o}}=0,789$ & $\grave{\mathrm{o}}=0,801$ & & \\
\hline \multirow[b]{2}{*}{$b_{3}=0,79$} & $c_{3}=0,67$ & $c_{4}=0,71$ & $c_{1}=0,59$ & $c_{2}=0,63$ & \multirow[t]{2}{*}{0,811} & \multirow{2}{*}{$\begin{array}{c}c_{3}=0,67 \\
\tilde{\mathrm{o}}=0,798\end{array}$} \\
\hline & $\grave{\mathrm{o}}=0,798$ & $\grave{\mathrm{o}}=0,811$ & $\grave{\mathrm{o}}=0,810$ & $\grave{\mathrm{o}}=0,826$ & & \\
\hline \multirow[b]{2}{*}{$b_{4}=0,85$} & $c_{4}=0,71$ & $c_{3}=0,67$ & $c_{2}=0,63$ & $c_{1}=0,59$ & \multirow[t]{2}{*}{0,844} & \multirow{2}{*}{$\begin{array}{l}c_{4}=0,71 \\
\tilde{\mathrm{o}}=0,800\end{array}$} \\
\hline & $\grave{\mathrm{o}}=0,832$ & $\grave{\mathrm{o}}=0,840$ & $\grave{\mathrm{o}}=0,847$ & $\grave{\mathrm{o}}=0,855$ & & \\
\hline$\widetilde{\tilde{\mathrm{o}}}_{i}$ & 0,777 & 0,789 & 0,800 & 0,813 & ö $=$ & 0,795 \\
\hline
\end{tabular}

The average values of the indicator ò of pedagogical tests calculated from the corresponding columns, equal to $0.777 ; \ldots ; 0.813$, reflect the degree of influence of the Rfactor of the structure of pedagogical tests on the value of the indicator ò. By the values of $\mathrm{j}$, as the result of calculating by rows, one can judge the degree of influence of the S-factor of pedagogical tests: $\tilde{j}$, equal to $0.745 ;. .$. ;
0.844. In the rightmost column are the values of the indicator ò for various latencies $\mathrm{L}$ of pedagogical tests: õk, equal to $0.788 ; \ldots ; 0,800$.

To conduct a variance analysis of the research results, a design scheme common to this type of planning was applied

(table 4).

Table 4 Analysis of variance of the results of studies of ò in the framework of plan of a model experiment on the type of Latin square $4 \times 4$

\begin{tabular}{|c|c|c|c|c|c|c|}
\hline \multirow[t]{2}{*}{ Dispersion source } & \multicolumn{2}{|c|}{$\begin{array}{c}\text { Number of degrees of } \\
\text { freedom }\end{array}$} & \multicolumn{2}{|c|}{ Sum of squares } & \multicolumn{2}{|c|}{ Average square } \\
\hline & Formula & Value & Formula & Value & Formula & Value \\
\hline $\begin{array}{c}\text { Lines b - S content of } \\
\text { pedagogical tests }\end{array}$ & $\mathrm{n}-1$ & 3 & $\mathrm{~s}_{b}{ }^{2}=\mathrm{s}_{2}{ }^{2}-\mathrm{S}_{5}{ }^{2}$ & 0,681 & $\mathrm{~s}_{b}{ }^{2} /(\mathrm{n}-1)$ & 0,227 \\
\hline $\begin{array}{c}\text { Columns a - } \\
\text { representativeness of the } \\
\text { structure R of pedagogical } \\
\text { tests }\end{array}$ & $\mathrm{n}-1$ & 3 & $\mathrm{~s}_{a}^{2}=\mathrm{s}_{3}{ }^{2}-\mathrm{S}_{5}^{2}$ & 0,662 & $\mathrm{~s}_{a}^{2} /(\mathrm{n}-1)$ & 0,221 \\
\hline $\begin{array}{c}\text { Letters C - Latency L } \\
\text { Pedagogical Tests }\end{array}$ & $\mathrm{n}-1$ & 3 & $\mathrm{~S}_{c}^{2}=\mathrm{S}_{5}^{2}-\mathrm{S}_{4}^{2}$ & 0,660 & $\mathrm{~s}_{c}{ }^{2} /(\mathrm{n}-1)$ & 0,220 \\
\hline Variance error & $\begin{array}{l}(\mathrm{n}-1) \\
(\mathrm{n}-2)\end{array}$ & 6 & $\begin{array}{l}\mathrm{S}^{2}{ }_{\text {ост }}=\mathrm{S}_{\text {общщ }}^{2}- \\
\left(\mathrm{s}_{a}^{2}+\mathrm{S}_{b}{ }^{2}+\mathrm{s}_{c}{ }^{2}\right)\end{array}$ & 0,221 & $\begin{array}{c}\mathrm{s}^{2}{ }_{\text {ocr }} / \\
(\mathrm{n}-1) \cdot(\mathrm{n}-2)\end{array}$ & 0,037 \\
\hline
\end{tabular}


presentation of educational information on enhancing students' creativity, Eu. Soc. Sci. J., 6 (2017) 194-200. since the variation of factors is carried out at four levels for each of the estimated factors: $\mathrm{S}, \mathrm{R}$ and $\mathrm{L}=$ var. The calculation was reduced to the calculation of such quantities as: the sum of the squares of all experiments $\mathrm{s}^{2}$; the sum of the squares of the row totals divided by the number of elements in each row $\mathrm{s}^{2}$; the sum of the squares of the column totals divided by the number of elements in each column $\mathrm{s}^{2}$; the sum of the squares of the results of the successive summation of $s 4^{2}$ for $\mathrm{k}=1,2,3$, 4 , divided by the number of elements corresponding to each index and the correcting term $\mathrm{s} 5^{2}$; equal to the square of the total divided by the total number of experiments.

From comparing the mean square values according to the F-criterion, it follows that the S-factor of pedagogical tests has a greater influence on the value ò: $\mathrm{FS}=0.227 / 0.037=$ $6.16>$ F critical. $0.05(3 ; 6)=4.76$. Significantly, the influence of the R-factor of the structure of pedagogical tests should be recognized: $\mathrm{FR}=0.221 / 0.037=6.00$ and latency L of pedagogical tests: $\mathrm{FL}=0.220 / 0.037=5.97$. An analysis of the changes shows that it significantly increases with increasing values of the S-factor, while the influence of the R- and L-factors of pedagogical tests is less than the influence of the factor $\mathrm{S}$ more than 2.5 times for $\mathrm{R}$ and 15 times for $\mathrm{L}$ pedagogical tests. To obtain reliable results of the test control, first of all, attention should be paid to their content $\mathrm{S}$ in conjunction with the representativeness $\mathrm{R}$ of the structure of pedagogical tests: the most reliable results of the test control should be expected precisely when the pedagogical tests meet precisely the requirements for the completeness and weight of these parameters.

\section{DISCUSSION AND CONCLUSION}

Planning the test control of pedagogical tests significantly increases the reliability of the results of diagnosing knowledge, skills, and the degree of formation of students' professional competencies [42-50, etc.]. The revealed correlations of the factors of pedagogical tests S, R and L are the starting points for determining and scientific substantiation of the organizational and pedagogical conditions for the qualimetric assessment of the professional achievements of future specialists in the context of an environmentally and economically safe sphere of activity to ensure the achievement of the main goals of sustainable development of society.

\section{ACKNOWLEDGMENT}

The reported study was funded by RFBR, project number 19-29-07209.

\section{REFERENCES}

[1] V. A. Belevitin, Ye. A. Gafarova, Yu. Korchemkina, O.N. Schwarzkop, Influence of ternary
[2] S. A. Bogatenkov, V. A. Belevitin, M. L. Khasanova, Risk Management Based on Model of Competences when Introducing Innovative Information Technology, Int. J. of Eng. \& Tech., vol.7-4.38 (2018) 78-81.

[3] V. A. Belevitin, S. A Bogatenkov., V. V. Rudnev, Integrated Approach to Modeling IC Competence in Students, Int.1 J. of Engineering \& Technology, v.7, No 4.38. (2018) pp. 60-62.

[4] Ye. Gafarova, V. Belevitin, Yu. Korchemkina, The Approbation of a Mathematical Model of the Influence of Three-Level Semantic Representation of a Educational Message on the Dynamics of Students' Creativity. Int. J. of Engineering \&Technology, v. 7(4.38) (2018) 171-173.

[5] S. A. Bogatenkov, The system of information training for work in the 1C environment: studies. allowance. Chelyabinsk: Publishing house Chelyab. state ped. University, 2014, 170 p.

[6] S. A. Bogatenkov, The system of formation of information and communication competence: studies. allowance. Chelyabinsk: Publishing House of ChGPU, 2014, $297 \mathrm{p}$.

[7] E. F. Zeer, E. M Dorozhkin, Main trends in the renewal of vocational education in a post-industrial society. On Sat materials vseros. (with international participation) scientific-practical. Conference "Transprofessionalism as a predictor of social and professional mobility of young people, Nizhny Tagil, 2019, pp.167-171.

[8] A.V. Eremina, I.V. Zoroastrova, Ye.O. Suchkova, Identification of key competencies of university graduates, International electronic scientific J. 4 (2015). http://sthum.ru/content/eremina-av-zoroastrova-ivsuchkova-eo-identifikaciya-klyuchevyh-kompetenciyvypusknikov.

[9] Atlas of new professions, Agency for strategic initiatives, The second edition, Skolkovo, 2015, 288 p.

[10]V.I. Blinov, B.A. Sazonov, The National Qualifications Framework of the Russian Federation, FGU FIPO, Center for Primary, Secondary, Higher, and Additional Professional Education, 2010, 7 p.

[11]Order of the Ministry of Labor and Social Protection of the Russian Federation No. 608n of 
Bulletin of the Voronezh Institute of the Ministry of Internal Affairs of Russia, 3 (2015) 36-44.

[23]E.V. Yakovlev, Pedagogical experiment: qualimetric aspect: monograph, Chelyabinsk: Publishing house of ChGPU, 1998, $136 \mathrm{p}$.

[24]I. D. Stolbova, A. N. Danilov, Toolkit for Evaluating Educational Results in the CompetencyBased Approach, Standards and Monitoring of Education, 4 (2012) 24-30.

[25]Danilov A.N., A.A. Ovchinnikov, M.B. Gitman, V.Yu. Stolbov, On an Approach to Assessing the Level of Formation of Competences of a University Graduate, Modern Problems of Science and Education, 6 (2014). http://science-education.ru/ru/article/view?id=15324.

[26]D.G. Miroshin, Assessment of the level of formation of students' professional competencies in technical subjects. http://pedagogika.snauka. $\mathrm{ru} / 2015 / 02 / 3313$.

[27]O. F. Shikhova, Yu.A. Shikhov, Qualimetric approach to the diagnosis of competencies of graduates of higher education, Education and Science, 4 (103) (2013) 40-57.

[28]A. Davies, D. Fidler, M. Gorbis, Future Work Skills 2020. Institute for the Future for the University of Phoenix Research Institute, 2012. http://goo.gl/N5MXWz.

[29]Pedagogical testing in the system of education quality. Technology ofcreation_of_test_materials.

[30]T. E. Klimova, Methods of correlation analysis in pedagogy: uch.-method, allowance. Magnitogorsk, Moscow State University, 2000, 96 p.

[31]M. Yu. Katina, V. A. Belevitin, A. V. Suvorov, On the Compliance of Pedagogical Tests to the Assessed Field of Knowledge of Academic Disciplines and the Level of Formed Skills and Professional Competences, Sb.- nauch. Proceedings VII International scientificpractical conference "Innovative technologies in the preparation of modern professional staff: experience, problems". Chelyabinsk, Chelyab. Branch of RANEPA, 2016, pp. 77-83.

[32]N. I. Ryzhova, Methodical theory: clarification of concepts, Problems and prospects for the development of teaching mathematics, Publishing House of the RSU. A.I. Herzen, 1999, pp. 3-9.
[22]A.N. Kopylov, V.V. Smaller, E.N. Sereda, Mathematical model of optimizing the trajectory of training internal affairs officers in emergency cases, 
[47]G. U. Matushansky, R. F. Bakeeva, Designing of pedagogical tests on the basis of mathematical methods. https://cyberleninka.ru/article/v/proektirovaniepedagogicheskih-testov-na-baze-matematicheskihmetodov.

Pedagogical tests and their content, structure, forms and types. Functions of tests. https://superinf.ru/view_helpstud.php?id=3435.

[35]A. N. Mayorov, The theory and practice of creating tests for the education system, Intellect-Center, 2001, 296 p. https://www.twirpx.com/file/309183/.

[36]I.K. Sirotina, Calculation and analysis of the characteristics of the test. http:// tester.quali.me/help.php.

[37]Neyman Yu. M. Introduction to the theory of modeling and parameterization of pedagogical tests. M .: Prometheus, 2000, 168 p.

[38]A. I. Samylovsky, Test as an Objective Measuring Tool in Education, Test Questions in Education, 1 (2001) 10-39.

[39]O. F. Shikhova, L. A. Gabdullina, Criteria for assessing the «ob"yektivirovannosti» of pedagogical control materials, Educ. and Sci., 3 (2000) 82-85.

[40]V.M. Glushkov, Introduction to ACS. Ed. 2nd Kiev, Technique, 1974.

[41]A. A. Sannikov, N. V. Kutsubina, System analysis in decision making: studies. allowance. Yekaterinburg: Ural. state forestry Univ., 2015, 137 p.

[42]Avanesov B. C. Fundamentals of the scientific organization of pedagogical control in higher education: studies, Allowance, 1989.

[43]V.S. Cherepanov, Expert methods in pedagogy: studies, Allowance, Publishing house of PSPI, 1988, 88 p.

[44]M.B. Chelyshkova, Development of pedagogical tests based on modern mathematical models: studies, Issled. Center for problems of improving the quality of training, 1995, $32 \mathrm{p}$.

[45]Research Center for Testing of the Ministry of Education of the Russian Federation "Pedagogical Measurements in Russia", 2001-2002.

[46]G. U. Matushansky, Designing pedagogical tests for knowledge control, Computer Science and Education, 6 (2000) 7-10; 11(2000) 40-41.
[48]P. I. Obraztsov, Scientific and methodological foundations of the design and construction of criterionoriented pedagogical tests. Scientific notes of Orel State University, 2(52) 2013. nauchnometodicheskie-osnovyproektirovaniya-i-konstruirovaniya-kriterialnoorientirovannyh-pedagogicheskih-testov.pdf.

[49]V.V. Belous, A.S. Domnikov, Test method for monitoring the quality of education and the criterion for the quality of educational tests, Review, Sci. and Educ., 4 (2011) 1-28.

[50]A.A. Kalmykov, An expert system for evaluating the conceptual composition of students' knowledge. http://www.nsu.ru/archive/conf/nit/97/c1/node5.html. 